\title{
Ameliorative Effect of Carica papaya Seed Extract on Diabetic Rat Model with Muscle Atrophy
}

\section{Devyani Diah Wulansari ${ }^{1}$, Devyana Dyah Wulandari ${ }^{2}$, Reine Risa Risthanti ${ }^{1}$, and Aguslina Kirtishanti ${ }^{1}$}

${ }^{1}$ Faculty of Pharmacy, University of Surabaya, Surabaya, Indonesia
${ }^{2}$ Faculty of Health, Nahdhatul Ulama University, Surabaya, Indonesia

Correspondence: Devyani Diah Wulansari

Email: devyanidiahwulansari@staff.ubaya.ac.id

Submitted: 04-10-2019, Revised: 13-11-2019, Accepted: 15-11-2019

\begin{abstract}
This study aims to prove that papaya seed extract has the potential to improve muscle cell atrophy in diabetic conditions. Type 2 diabetes mellitus (DM) animal model were made with conditions similar to type 2 DM in humans i.e. with long-term (56 days) high sugar (fructose) consumption. Then, the next 14 days were treated with papaya seed extract at the dose of 100, 200, and $300 \mathrm{mg} / \mathrm{kg} \mathrm{BW}$ orally. Body weight and blood glucose levels were monitored throughout the study period. At the end of the study, histopathological examination of gastrocnemius skeletal muscle tissue was carried out using hematoxylin-eosin staining and measuring myocyte cell area. Results showed that there is a correlation between blood glucose levels with the area of muscle cells which explains that the decrease in blood glucose levels is in line with the increase in the area of muscle fiber cells. In the diabetic group and the treatment group the dose of $100 \mathrm{mg} / \mathrm{kg} \mathrm{BW}$ has a smaller area, whereas in the treatment group the dose of 200 and $300 \mathrm{mg} / \mathrm{kg} \mathrm{BW}$ has an area close to the area of the muscle cell in the normal group. This is supported by the results of measurements of the area of muscle fiber cells observed through cross sections and measured at the end of this study. The treatment group at the dose of 200 and $300 \mathrm{mg} / \mathrm{kg}$ $B W$ did not have significant difference $(P>0.05)$ compared to the normal group. It can be concluded that papaya seed extract therapy at the dose of 200 and $300 \mathrm{mg} / \mathrm{kg} \mathrm{BW}$ on diabetic rats can reduce the fasting blood glucose levels so that it can ameliorate cell atrophy in the diabetic conditions.
\end{abstract}

Keywords: Carica papaya seed; muscle cell atrophy; diabetic rat 


\section{Introduction}

The development of health in Indonesia is increasing, as evidenced by more and more health innovations to improve public health. Although its development is quite rapid, Indonesia has health problems that are still a burden and a major challenge in the world of health. NCD World Health Organization (WHO) reports that $60 \%$ of the causes of death in the world are Non-Communicable Diseases (NCD). Diabetes mellitus (DM) is $6^{\text {th }}$ rank as a cause of death. WHO predicts an increase in the number of DM in Indonesia from 8.4 million people in 2000 increased 2-3 times to around 21.3 million in 2030. Whereas the International Diabetes Federation (IDF) predicts an increase in the number of people with DM in Indonesia, from 9.1 million people in 2014 to 14.1 million in 2030. Diabetes mellitus is a disease that can reduce the quality of human resources and have big impact on increasing of health costs. Therefore, management of DM requires the participation of both health workers such as doctors, pharmacists, as well as nurses and the patient's family in order to better understand the healthy lifestyle, prevention and management of DM. A good understanding will help improve efforts to manage DM in order to achieve better results [1].

Diabetes mellitus is caused by heterogeneous clinical and genetic disorders, marked by hyperglycemia due to insulin function insufficiency [2]. Type 2 diabetes is characterized by impaired insulin action or abnormal insulin secretion. Abnormalities that occur in type $2 \mathrm{DM}$ are insulin resistance where the insulin condition is unable to provide biological effects in the circulation at effective concentrations in normal subjects. Insulin resistance is a factor associated with metabolic syndrome including glucose intolerance, hypertension and dyslipidemia. Insulin resistance triggers decreased glucose uptake and glycogen synthesis in peripheral tissues. Disorders of glycogen storage in the liver and glycogen synthase activity are also related to the presence of insulin resistance. Resistance that occurs in the antili- polytic action of insulin affects the breakdown of triglycerides in adipose tissue and the formation of free fatty acids that can inhibit the action of insulin to stimulate glucose uptake and metabolism in skeletal muscle and stimulate gluconeogenesis in the liver and disrupt insulin receptor signals. In the initial phase II type DM, resistance to the action of insulin to reduce blood glucose results in a slight increase in blood glucose concentration, which stimulates insulin secretion and causes hyperinsulinemia. Initially, the condition of hyperinsulinemia can overcome insulin resistance. But along with the increasing development of the disease, prolonged insulin secretion cannot compensate for insulin resistance so that in fasting conditions and after eating hyperglycemia will occur [3].

Diabetes is associated with loss of muscle mass and strength as we age. Low muscle mass and poor muscle strength cause functional disorders in DM patient, especially in the elderly who are often known as sarcopenia. The incidence of sarcopenia in the elderly accompanied by DM increases the risk of functional impairment in some physical activities compared to the elderly without DM. Some studies have shown that the condition of glucose intolerance and insulin resistance correlates with muscle mass and strength [4]. Skeletal muscle is a major part that utilizes $80 \%$ glucose from the whole body which is stimulated by insulin and plays an important role in the pathogenesis of insulin resistance [5]. Skeletal muscle atrophy occurs in a diabetic state and is associated with a direct effect of low serum insulin. Morphometric studies describe a reduction in the area of muscle fiber cells in a diabetic state [6].

Herbal medicines have been developed for the management of type 2 DM. More than 1200 plants are claimed to have antihyperglycemic activity. 400 types of plants have been studied for the treatment of type 2 DM [7]. Papaya (Carica papaya L.) is widely cultivated plant in Indonesia and it is an economically valuable type of plant. Papaya seeds which are considered as waste 
have several health benefits. Ethnobotany survey shows that papaya seeds are widely used as herbs for the management of several diseases such as stomach discomfort, pain, malaria, diabetes, obesity, and infection. Papaya seeds are rich in proteins, lipids, and fiber. In addition, the polyphenol content in the form of phenolic acids and flavonoids in papaya seeds have high antioxidant activity and anti-hyperglycemia activity. Papaya seed extract is thought to reduce the rate of glucose absorption in the intestine, increase the use of glucose in the peripheral, stimulate the ability of pancreatic $\beta$ cells to produce insulin or improve pancreatic $\beta$ cells [8]. Papaya seed extract has also been investigated to increase GLUT 4 expression in the skeletal muscle cells of diabetic rats, thereby increasing glucose uptake into cells [9]. With increased expression of GLUT 4 in muscle cells it is expected to prevent atrophy.

Therefore, to prove that papaya seeds have the potential to improve muscle cell atrophy in diabetic conditions, this current study was carried out by observing changes in the extent of skeletal muscle cell fibers in diabetic model rat given papaya seed extract. This study aimed to prove that administration of papaya seed extract on diabetic rat can reduce blood glucose levels which correlate with improvement of cell atrophy.

\section{Materials and methods}

\subsection{Equipment and materials}

This study used a blood glucose meter, UV-Visible spectrophotometer, light microscope (Nikon H600L) which is equipped with a 300 megapixel DS Fi2 digital camera and micro-meter software that is encircled by the Nikon Image System. The materials used consisted of papaya seed, demineralized water, fructose solution (20\%), xylol, alcohol, hematoxylin solution, eosin solution, and diethyl ether.

\subsection{Animal handling}

This study used 40 rats (Rattus norwegicus) wistar strain with the body weight of 200-300 g. The study design was completely randomized design Posttest control group design. Animals were divided into 4 groups i.e. one negative control group (diabetic) and 3 treatment groups which were given papaya seed extract in the dose of 100 , 200 , and $300 \mathrm{mg} / \mathrm{kg} \mathrm{BW}$, respectively. All groups were given normal feed and drink ad libitum. The body weight of animals was weighed at the beginning, before and after induction of type 2 DM, and at the end of the study. All animals were adapted for 14 days, then oral fructose solution at a dose of $9 \mathrm{~g} / \mathrm{kg}$ BW was given on the day of 15 for 56 days. It was expected to induce type 2 DM. After 56 days of fructose administration, rats were fasted for 6 hours then blood glucose levels were measured. Rats with blood glucose levels of more than $150 \mathrm{mg} / \mathrm{dL}$ were then used in this study as treatment and control groups. Furthermore, the treatment group was given papaya seed extract for 14 days while the control group was only given carrier solvent. On the day of 84 , all animals were sacrificed, after being fasted 6 hours before. Test animals were anesthetized using diethyl ether by inhalation. The rat is then dissected from the abdomen using a scalpel until the heart is visible. Furthermore, intracardiac blood is taken using a $23 \mathrm{G}$ needle with a $5 \mathrm{ml}$ syringe. Blood samples were subsequent used to analyze blood glucose levels by enzymatic methods using a spectrophotometer. Intake of skeletal muscle tissue was carried out in the gastrocnemius portion of each group of rats at the end of the study. The tissue is then fixed with $10 \%$ formalin neutral buffer for histological analysis using Hematoxylin-Eosin staining.

\subsection{Preparation of papaya seed extract}

Ripe papaya fruits were cut into 2 parts, then the seeds were taken and washed twice with tap water. The seeds were then dried at room temperature for 4 weeks and ground using a blender. $500 \mathrm{~g}$ of papaya seed powder was macerated with $70 \%$ alcohol for approximately 3 days, then filtered using white cotton cloth and a Buchner 
funnel. The extract was then evaporated at $40^{\circ} \mathrm{C}$ to produce a thick, sweet-smelling brown extract. The extraction process was repeated four times and the resulted solid powder was weighed and stored in an airtight container, then put in a refrigerator $\left(4^{\circ} \mathrm{C}\right)$.

\subsection{Gastrocnemius muscle histopathological exa- mination}

This examination aimed to determine the area $\left(\mu \mathrm{m}^{2}\right)$ of myocyte cells in rat. Data on myocyte cell area was obtained by calculating the average area of five myocyte cells selected from five different areas at 400x magnification. The entire examination used a Nikon H600L ordinary light microscope which is equipped with a 300-megapixel DS Fi2 digital camera and a micrometer-encased Nikkon Image System software.

\subsection{Data analysis}

Data in each group was analyzed with the Kolmogorov-smirnov test to determine the normality of data distribution. Data were then analyzed using one way ANOVA $(\alpha=0.05)$. All statistical analysis were conducted using SPSS 20.0 for windows.

\section{Results and discussion}

This study uses a model approach to type $2 \mathrm{DM}$ that resembles humans. Fructose was used as a type 2 DM inducing compound with the consideration that fructose is able to trigger insulin resistance. Previous studies suggested that subjects who were given fructose for 10 weeks, would experience an increase in body weight of about 1-3 kg accompanied by a significant increase in instantaneous sugar levels and insulin levels [10].

The body weight of animal (Table 1 ) was measured at the beginning of the study to determine the inclusion criteria and evaluated during the acclimatization period. Weight loss of more than $10 \%$ is a consideration not to be used in this study. During the diabetes induction period and treatment, the body weight of animals was monitored to determine the dose of fructose solution and papaya seed extract as well as to evaluate the occurrence of hyperglycemia conditions.

Table 1 shows that body weight at the beginning and at the end of the study in all groups of animals were not significantly different. Similarly, fasting blood glucose level at the beginning of the study were not significantly different at all groups. However, it was significantly different at the end of the study. Treatment groups showed a decrease in blood glucose levels, especially the group treated with papaya seed extract at the dose of $300 \mathrm{mg} / \mathrm{kg} \mathrm{BW}$. The fasting blood glucose levels in the negative control and group treated with papaya seed extract at the dose of $300 \mathrm{mg} /$ kg BW were 190.17 and $136.83 \mathrm{mg} / \mathrm{dL}$, respectively. A decrease in fasting blood glucose level is followed by an improvement in the area of muscle fibers observed through cross sections and measured at the end of the study, as shown in Figure 1. It exhibited that the decrease in blood glucose levels is proportional to the increase in the area of muscle fiber cells (Figure 2).

Other studies have shown that fructose administration was able to decrease insulin sensitivity [11]. This was reinforced by a study in healthy people which showed a significant decrease in the Hepatic Insulin Sensitivity Index (HISI) after administration of fructose in various concentrations. Decreased sensitivity to insulin is strongly influenced by the dose of fructose entering the body. The greater dose will result in a significant decrease in insulin sensitivity [12]. Fructose was used as an inducer of type $2 \mathrm{DM}$ given at a dose of $9 \mathrm{~g} / \mathrm{kg} \mathrm{BW}$. This dose is capable of causing insulin resistance through the de novo lipogenesis process. The formation of fatty acids from excessive de novo lipogenesis can reduce insulin sensitivity, causing a decrease in glucose uptake by insulinsensitive tissue [13]. One protein on the cell surface playing an important role in the process of glucose uptake is GLUT4. Prolonged fructose induction can cause desensitization and downregulation of insulin receptors so that it can interfere 
Tabel 1. Body weight and fasting blood glucose level in the diabetic and the treatment rat group at the initial and final of study

\begin{tabular}{|c|c|c|c|c|}
\hline \multirow{2}{*}{ Animal } & \multicolumn{2}{|c|}{ Body weight (g) } & \multicolumn{2}{|c|}{ Fasting blood glucose level (mg/dL) } \\
\hline & Initial & Final & Initial & Final \\
\hline \multicolumn{5}{|c|}{ Diabetic Rat } \\
\hline 1 & 188 & 276 & 115 & 240 \\
\hline 2 & 192 & 277 & 109 & 204 \\
\hline 3 & 207 & 323 & 113 & 217 \\
\hline 4 & 220 & 337 & 95 & 159 \\
\hline 5 & 185 & 291 & 104 & 164 \\
\hline 6 & 199 & 330 & 123 & 157 \\
\hline Mean \pm SD & $199 \pm 13$ & $306 \pm 28$ & $110 \pm 10$ & $190 \pm 35$ \\
\hline \multicolumn{5}{|c|}{ CPs (100 mg/kg BW) } \\
\hline 1 & 232 & 332 & 104 & 135 \\
\hline 2 & 229 & 302 & 96 & 166 \\
\hline 3 & 190 & 280 & 113 & 179 \\
\hline 4 & 197 & 272 & 106 & 138 \\
\hline 5 & 224 & 316 & 109 & 157 \\
\hline 6 & 180 & 223 & 117 & 152 \\
\hline Mean \pm SD & $209 \pm 22$ & $288 \pm 39$ & $108 \pm 7$ & $155 \pm 17$ \\
\hline \multicolumn{5}{|c|}{ CPs $(200 \mathrm{mg} / \mathrm{kg} \mathrm{BW})$} \\
\hline 1 & 217 & 365 & 94 & 180 \\
\hline 2 & 202 & 259 & 107 & 112 \\
\hline 3 & 162 & 297 & 106 & 164 \\
\hline 4 & 178 & 260 & 93 & 133 \\
\hline 5 & 168 & 234 & 124 & 127 \\
\hline 6 & 195 & 237 & 108 & 167 \\
\hline Mean \pm SD & $187 \pm 21$ & $275 \pm 49$ & $105 \pm 11$ & $147 \pm 27$ \\
\hline \multicolumn{5}{|c|}{ CPs $(300 \mathrm{mg} / \mathrm{kg} B W)$} \\
\hline 1 & 172 & 337 & 108 & 135 \\
\hline 2 & 212 & 327 & 109 & 124 \\
\hline 3 & 202 & 330 & 130 & 147 \\
\hline 4 & 198 & 275 & 97 & 120 \\
\hline 5 & 205 & 249 & 134 & 139 \\
\hline 6 & 168 & 291 & 120 & 156 \\
\hline Mean \pm SD & $193 \pm 18$ & $302 \pm 35$ & $116 \pm 14$ & $137 \pm 14$ \\
\hline P value & 0.272 & 0.523 & 0.357 & 0.007 \\
\hline
\end{tabular}

CPs: Carica papaya seed extract

with intracellular GLUT4 translocation into the plasma membrane of skeletal muscle cells which subsequently causes a decrease in glucose uptake by insulin-sensitive tissues such as skeletal muscles, causing hyperglycemia conditions $[9,14]$.

In this study, the results showed that in hyper- glycemic conditions, the area of skeletal muscle cells in rat gastrocnemius was smaller (Figure $3 b$ ) than those of normal rat (Figure 3a). In this case it is known as cell atrophy. This can be caused by decrease of glucose uptake, a source of energy for cell metabolism. The process of skeletal 


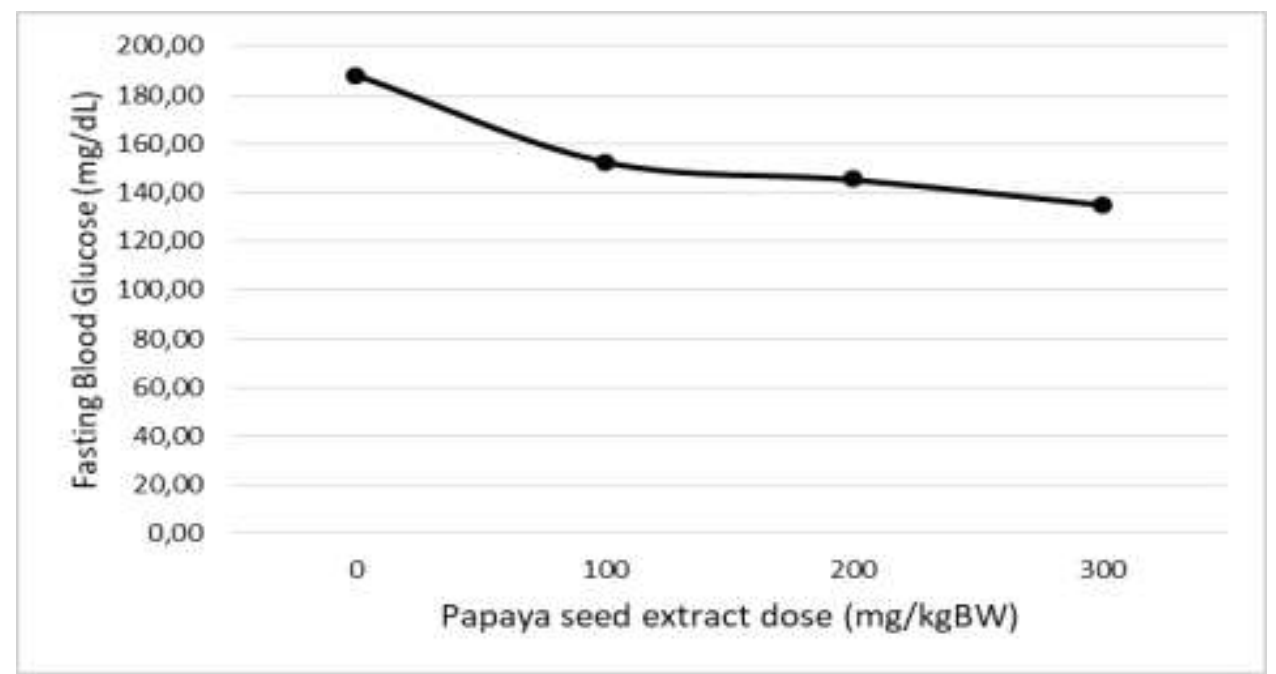

Figure 1. The relationship between papaya seed extract dose with the blood glucose levels in diabetic rat

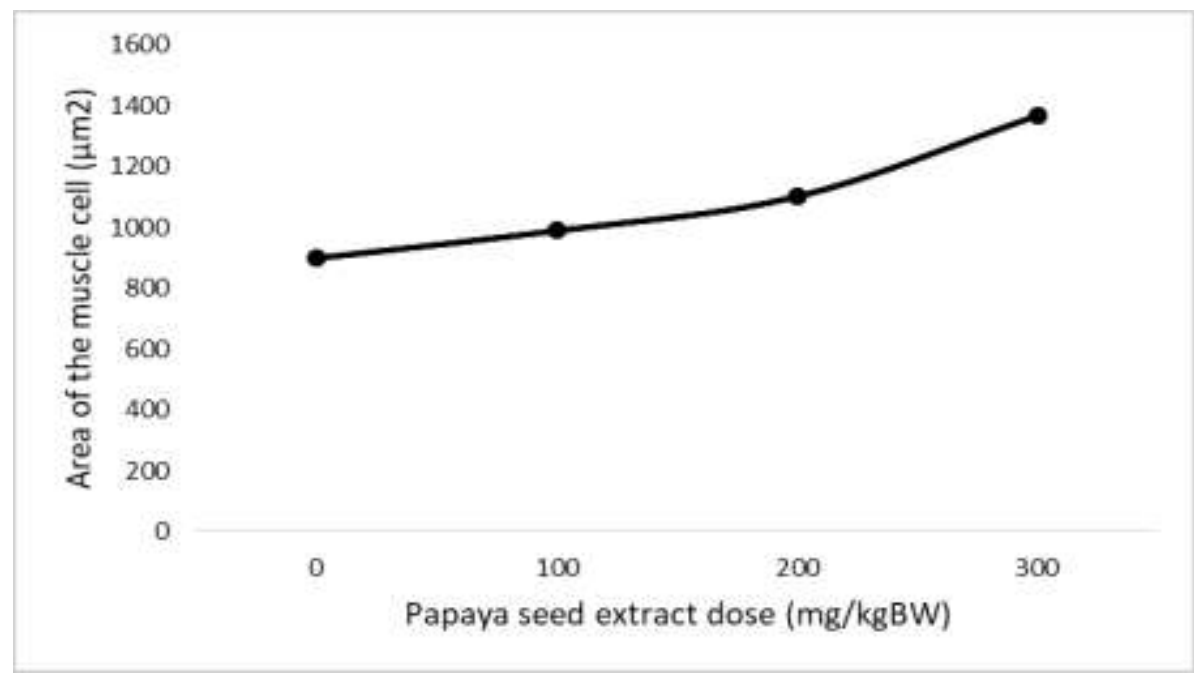

Figure 2. The relationship between papaya seed extract dose with the area of skeletal muscle cells in diabetic rat

muscle cell atrophy can be caused by a decrease in the amount of insulin and involves several mechanisms including disruption of metabolic processes, changes in blood vessels, degeneration of motor end plates and damage to myocyte protein synthesis [6]. Decreased insulin response in hyperglycemia condition can also be caused by mTOR inhibition, which causes impaired insulin action on glucose metabolism in skeletal muscle. Insulin resistance can also decrease muscle cell area by suppressing the PI3K-Akt signal pathway, which leads to activation of caspase- 3 and proteolytic pathways and results in the degradation of muscle protein [15]. Damage to the PI3K-Akt pathway plays a role in reducing insulin-media- ted glucose uptake and protein synthesis in mice and patients with T2DM [11].

Table 2 shows that the area of gastrocnemius muscle fibers in cross section in the diabetic and the treatment group (100 mg/kg BW) were significantly different from normal group with $\mathrm{P}$ values of 0.008 and 0.033 , respectively. Otherwise, treatment group with the doses of 200 and $300 \mathrm{mg} / \mathrm{kg}$ BW did not have a significant difference compared to the normal group ( $\mathrm{P}>0.05)$. It revealed that the administration of papaya seed extract was significantly able to ameliorate the area of skeletal muscle cells in diabetic rats approaching normal condition. Papaya seed extract is rich in flavonoids and phenolic acid having important 


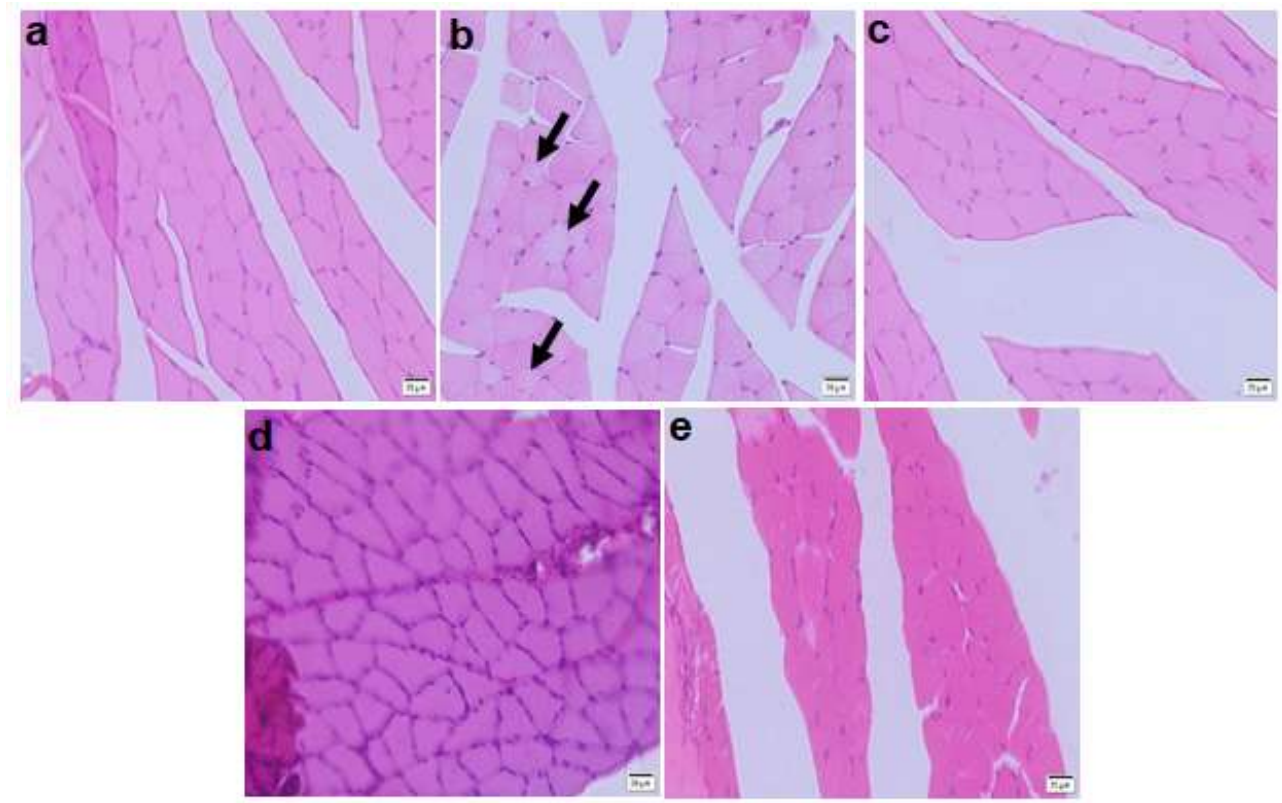

Figure 3. Histopathological features of gastrocnemius skeletal muscle with hematoxylin-eosin staining: normal rat (a), diabetic rat (b), diabetic rat treated with papaya seed extract at the dose of 100 mg/kg BW (c), $200 \mathrm{mg} / \mathrm{kg}$ BW (d), and $300 \mathrm{mg} / \mathrm{kg} \mathrm{BW} \mathrm{(e);} \mathrm{arrows} \mathrm{indicate} \mathrm{cells} \mathrm{with} \mathrm{atrophy.}$

Tabel 2. Cross section of gastrocnemius skeletal muscle cell area of test animal

\begin{tabular}{|c|c|c|c|c|c|}
\hline \multirow{3}{*}{ No. } & \multicolumn{5}{|c|}{ Cross section area of muscle fiber $\left(\mu \mathrm{m}^{2}\right)$} \\
\hline & & Diabetic rat & & & \\
\hline & Normal rat & $\begin{array}{l}\text { Negative } \\
\text { control }\end{array}$ & $\begin{array}{l}\text { CPs }(100 \mathrm{mg} / \mathrm{kg} \\
\text { BW) }\end{array}$ & $\begin{array}{l}\text { CPs }(100 \mathrm{mg} / \mathrm{kg} \\
\text { BW) }\end{array}$ & $\begin{array}{l}\text { CPs }(200 \mathrm{mg} / \mathrm{kg} \\
\text { BW) }\end{array}$ \\
\hline 1 & 1945.23 & 935.65 & 952.18 & 1142.82 & 1370.71 \\
\hline 2 & 1348.37 & 953.35 & 699.39 & 941.77 & 1100.06 \\
\hline 3 & 921.06 & 764.66 & 952.18 & 1118.51 & 1649.49 \\
\hline 4 & 1646.5 & 910.63 & 966.13 & 1443.15 & 1515.59 \\
\hline 5 & 1433 & 970.30 & 1273.69 & 927.17 & 1273.68 \\
\hline 6 & 1134.53 & 868.49 & 1100.07 & 1042.40 & 1300.66 \\
\hline $\begin{array}{l}\text { Mean } \pm \\
\text { SD }\end{array}$ & $1404.78 \pm 363.73$ & $900.51 \pm 75.47$ & $990.61 \pm 211.37$ & $1102.64 \pm 188.74$ & $1368.37 \pm 155.30$ \\
\hline P value & & 0.0077 & 0.0329 & 0.1010 & 0.8329 \\
\hline
\end{tabular}

*compared to the normal rat; CPs: Carica papaya seed extract

role as antioxidants and anti-hyperglycemia. Previous studies have shown that papaya seed extract can increase GLUT4 expression in hyperglycemic mice so that it can increase glucose uptake into insulin sensitive tissue [9]. The results of this study indicated that papaya extract at a dose of 200 and $300 \mathrm{mg} / \mathrm{kg} \mathrm{BW}$ were able to improve the atrophy of skeletal muscle cells that occurs in hyperglycemia conditions.

Based on the above data it can be observed that there is a correlation between blood glucose levels with the area of muscle cells as shown in Figure 1. It explained that the decrease in blood glucose levels is proportional to the increase in the area of muscle fiber cells. This can also be seen from the histopathological picture (Figure 2). Diabetic group and the treatment group (100 $\mathrm{mg} / \mathrm{kg} \mathrm{BW}$ ) had smaller area, whereas the treatment groups (200 and $300 \mathrm{mg} / \mathrm{kg} \mathrm{BW}$ ) had area close to those of the normal group.

This research provide insight that Indonesian native plants that have been widely used, papaya, 
can improve the muscle cell atrophy in hyperglycemia condition. It was predicted through its role in improving insulin sensitivity by increasing GLUT4 expression and regulating pathways PI3KAkt signals that are important in the process of glucose uptake in insulin sensitive tissues such as muscles. It is hoped that papaya seed extract can be used as a potential alternative therapy in cell atrophy conditions due to type $2 \mathrm{DM}$.

\section{Conclusions}

It can be concluded that papaya seed extract therapy at the dose of 200 and $300 \mathrm{mg} /$ $\mathrm{kg}$ BW on diabetic rats can reduce the fasting blood glucose levels so that it can ameliorate cell atrophy in the diabetic conditions.

\section{References}

1. Indonesia PE. Konsensus pengelolaan dan pencegahan diabetes melitus tipe 2 di Indonesia. Jakarta: PB Perkeni; 2015:1-58.

2. Depertemen Kesehatan RI. Profil kesehatan Indonesia. Jakarta: Departemen Kesehatan RI; 2015.

3. Fernandez C, Joseph P. Molecular basis of type-2 diabetes. Molecular Endocrinology. 2006;37(3):190-3.

4. Kalyani RR, Metter EJ, Ramachandran R, Chia CW, Saudek CD, Ferrucci L. Glucose and insulin measurements from the oral glucose tolerance test and relationship to muscle mass. Journals of $\mathrm{Ge}-$ rontology Series A: Biomedical Sciences and Medical Sciences. 2011;67(1):74-81.

5. Phielix E, Mensink M. Type 2 diabetes mellitus and skeletal muscle metabolic function. Physiology \& Behavior. 2008;94(2):252-8.

6. Aughsteen AA, Khair AMB, Suleiman AA. Quantitative morphometric study of the skeletal muscles of normal and streptozotocin-diabetic rats. Journal of the Pancreas. 2006;7(4):382-9.
7. Chang C, Lin Y, Bartolome A, Chen YC, Chiu SC, Yang WC. Herbal therapies for type 2 diabetes mellitus: chemistry, biology, and potential application of selected plants and compounds. Evidence-Based Complementary and Alternative Medicine. 2013:133.

8. Vankateshwarlu, Dileep, Reddy RK, Sandhya. Evaluation of anti-diabetic activity of Nishamlaki on streptozotocin induced type II diabetic rats. International Journal of Phytomedicine. 2015; 6(4):595600.

9. Wulansari DD, Basori A, Suhartati S. Effect of papaya seed extract (Carica papaya Linn.) on glucose transporter 4 (GLUT 4) expression of skeletal muscle tissue in diabetic rat induced by high fructose diet. Majalah Obat Tradisional. 2017;22(2):131-8.

10. Tappy L. Q\&A:'Toxic' effects of sugar: should we be afraid of fructose? BMC Biology. 2012;10(1):1-7.

11. Stanhope KL, Schwarz JM, Keim NL, Griffen SC, Bremer AA, Graham JL, Hatcher B, Cox CL, Dyachenko A, Zhang W, McGahan JP. Consuming fructose-sweetened, not glucose-sweetened, beverages increases visceral adiposity and lipids and decreases insulin sensitivity in overweight/ obese humans. The Journal of Clinical Investigation. 2009;119(5):1322-34.

12. Livesey G. Fructose Ingestion: dose-dependent responses in health research. The Journal of Nutrition. 2009;139(6):1246S-52S.

13. Wulansari DD, Wulandari DD. Pengembangan model hewan coba tikus diabetes mellitus tipe 2 dengan induksi diet tinggi fruktosa intragastrik. Media Pharmaceutica Indonesiana. 2018;2(1):41-7.

14. Hajiaghaalipour F, Khalilpourfarshbafi M, Arya A. Modulation of glucose transporter protein by dietary flavonoids in type 2 diabetes mellitus. International Journal of Biological Sciences. 2015;11(5):508-24.

15. Zhang J, Zhuang P, Wang Y, Song L, Zhang M, Lu Z, Wang J, Alemu PN, Zhang Y, Wei H, Li H. Reversal of muscle atrophy by Zhimu-Huangbai herb-pair via Akt/mTOR/Fox03 signal pathway in streptozotocininduced diabetic rat. PLoS ONE. 2014;9(6):1-10. 